\title{
Chinese ELF Learners' Acquisition of Modal Verbs: A Corpus-Based Study
}

\author{
Yan Xiao ${ }^{1}$ \\ ${ }^{1}$ School of Foreign Languages, Jiangsu University, Zhenjiang, China \\ Correspondence: Xiao Yan, School of Foreign Languages, Jiangsu University, Zhenjiang, Jiangsu Province, \\ China. E-mail: xiaoyan80@sohu.com
}

Received: July 4, 2017 Accepted: August 2, 2017 Online Published: September 25, 2017

doi:10.5539/ijel.v7n6p164 URL: http://doi.org/10.5539/ijel.v7n6p164

\begin{abstract}
By adopting a corpus-based approach, the study explores how Chinese EFL learners differ from native English speakers in the use of modal verbs in different genres. Results show that Chinese EFL learners significantly overuse modal verbs both in speaking and writing. In addition, their overuses of the high-value modal verbs of must, should and have to also achieve the significant level. However, Chinese EFL learners significantly underuse the low-value modal verbs of would, might and could in comparison with native English speakers. It is hypothesized that Chinese EFL learners' improper uses of modal verbs are caused by the negative transfer from Chinese, in which the meaning potentials of modal verbs are different from those in English.
\end{abstract}

Keywords: modal verbs, acquisition, spoken language, written language

\section{Introduction}

Modal verbs, as a key means to express modality, substantiate their users' attitudes to the propositions or events being described in the utterances, and thus the use of these words could be viewed as a facet of pragmatic competence (Leech, 1983). Interpersonally speaking, appropriate use of modal verbs can not only enhance the acceptability of the utterances by being more euphemistic and polite, but also strengthen the mood by being more authorarive and imperative. For these reasons, modal verbs have received numerous research in linguistics since 1970s. A large body of research has been carried out to explore the use of these verbs by native speakers of English (Major, 1974; Biber et al., 1999; Papafragou, 2000; Salsbury \& Bardovi-Harlig, 2000), and some also investigated how non-native speakers acquire these words (Hu et al., 1982; Chang, 1987; Hinkel, 1995; Hyland \& Milton 1997; Aijmer, 2002; McEnery \& Kifle, 2002; Guo, 2005; Cheng \& Qiu, 2007). However, it needs to be pointed out that most of the existing research only examines the use of modal verbs in writing. Few studies are designed to explore the use of modal verbs in the spoken genre, and even fewer research discusses how L2 learners differ from native speakers in the use of modal verbs. Taking these into consideration, this paper explores how Chinese EFL learners differ from native English speakers in the use of modal verbs in speaking and writing in the hope of providing some suggestions for the teaching of English to non-native speakers.

\section{Literature Review}

Modality is a major semantic manifestation of the interpersonal meta-function of language ( $\mathrm{Li}, 2000)$. It is mainly instantiated or expressed by modal verbs, which convey its users' attitudes or views to the propositions being concerned. Thus, the use of modal verbs could serve as a good indicator of their users' mastery of modality. In this sense, it is of high value to examine the use of modal verbs by non-native English learners. Traditional grammar categorizes modal verbs into three groups by their semantic meanings, as in Table 1.

Table 1. Types of modal verbs in traditional grammar

\begin{tabular}{ll}
\hline Types & Modal verbs \\
\hline obligation, necessity & must; should; need; ought; have to; \\
volition, predication & will; would; shall; \\
possibility, ability & can; could; may; might; \\
\hline
\end{tabular}

Functional Grammar (Halliday, 1994, p. 358) also categorizes modal verbs into three groups according to 
probability, frequency, volition and obligation, as shown in Table 2.

Table 2. Types of modal verbs in functional grammar

\begin{tabular}{ll}
\hline Types & Modal verbs \\
\hline High-value & must; ought; need; have to; \\
Middle-value & will; would; shall; should; \\
Low-value & may; might; can; could; \\
\hline
\end{tabular}

By comparison, the two typologies are in accordance with each other. Those modal verbs to express obligation and necessity coincide with the category of high-value modals; those to express possibility and ability equal to the category of low-value ones; with those modals to express volition and predication in between. The only inaccordance concerns with the modal verb should. It is termed as a middle-value modal verb in Functional Grammar, though it is believed to convey obligation in Traditional Grammar. Taking into consideration the fact that should is used to convey the meaning of being required or obliged to undertake an action, it is operationalized as a high-value modal verb in the present study.

In Leech's (1983) politeness scale, the use of different modal verbs affects the degrees of politeness. The higher the values of the modal verbs are, the more oppressive the utterances would be, thus less polite than those with lower value modals. In contrast, the lower the values of the modal verbs are, the more uncertain the users are about the propositions, thus more polite than those with higher value modals.

Modal verbs, thus, are not only a means to convey its users' attitudes, but also a tool to indicate politeness. Therefore, they have been extensively studied in the literature. Among those, Biber et al. (1999, pp. 486-490) reveal that native English speakers employ those modals quite differently in different genres: as a whole, modals verbs occur more frequently in speaking than in writing; such modal verbs as can, will and could are mainly used in speaking; while the modals of may, must and would tend to occur more frequently in writing.

Because different cultures have different social cultural norms, the modal verb systems in different cultures in turn vary from one to another (Hinkel, 1995), and it is inevitable for non-native speakers to negatively transfer the modal system in their $\mathrm{L} 1$ to the $\mathrm{L} 2$ system, thus resulting in interlanguage pragmatic errors. For example, Hu et al. (1982) find that Chinese EFL learners tend to choose such high-value modal verbs as should and must, while native speakers prefer the use of had better and need in making requests or advice. Similarly, some other scholars (Hyland \& Milton, 1997; Yang, 1998; Wang, 2005) also reveal that Chinese EFL learners overuse such modal verbs as can, may, should and have to, while native speakers would choose could, might and would in similar contexts. Consequently, Wang (2005) and Cheng \& Qiu (2007) claim that Chinese EFL learners tend to overuse modal verbs in writing, which reflect the learners' monotony in expressing modality (Hong \& Yu, 2007).

Similar inappropriate use also exists among other Asian learners of English. For instance, Hinkel (1995) finds that English learners in Southeast Asia tend to overuse the high-value modals of must, should, have to, ought to, etc., which makes their utterances more oppressing than they are supposed to be.

Western learners of English might also utilize modal verbs inappropriately (Aijmer, 2002). Their choices, however, are quite different from Asian learners. Few research (McEnery \& Kifle, 2002) finds that English learners in western countries (especially in Europe) tend to overuse middle-value modal verbs to highlight their uncertainty and implicitness, but they seldom choose high-value modals. Kasper (1979) claims that those learners literally translate the modal verbs in their mother tongues into the target language, without noticing the different implications entrenched by the modals in different languages, thus leading to pragmatic failures in cross-cultural communication. This inappropriate use, in consequence, is more likely to be viewed as impolite or even as offensive by native speakers (Altman, 1990). Therefore, there is a consensus that L2 learners of English encounter difficulties in the use of modal verbs.

It can be seen that non-native speakers differ, by and large, from native speakers in the use of modal verbs. However, these findings are mainly generated from written language. Though modal verbs occur quite differently in different genres (Biber et al., 1999), it is still unclear how modal verbs are used by L2 learners in speaking, and whether L2 learners use these verbs differently in different genres (i.e., speaking and writing). Taking these into consideration, the present paper is designed to explore how Chinese EFL learners use modal verbs in speaking and writing, and how they differ from native speakers of English in different genres. 


\section{Methodology}

\subsection{Research Questions}

The study is designed to examine how non-native speakers differ in the use of modal verbs from native speakers of English in speaking and writing. Specifically, the study contains the following three research questions:

(1) How do Chinese EFL learners use modal verbs in different genres?

(2) How do native English speakers use modal verbs in different genres?

(3) How Chinese EFL learners differ from native English speakers in the use of modal verbs in different genres?

\subsection{Data Source}

In order to answer the above three questions, two corpora were analyzed. The native English speakers' data were taken from The British National Corpus (BNC for short hereafter), and the Chinese English learners' data were from The Spoken and Written English Corpus of Chinese Learners (SWECCL for short). Around 1 million tokens of each genre (i.e., spoken and written) were randomly selected from each corpus, as indicated in Table 3.

Table 3. Description of the data

\begin{tabular}{lll}
\hline Corpus & Genre & Data Size \\
\hline SWECCL & Speaking & $1,261,139$ \\
& Writing & $1,008,608$ \\
BNC & Speaking & $1,694,445$ \\
& Writing & $1,281,793$ \\
\hline
\end{tabular}

\section{Results}

\subsection{Chinese EFL Learners' Use of Modal Verbs}

It can be seen from Table 4 that Chinese EFL learners in general use more, though not significantly, modal verbs in writing than in speaking ( 229 vs. $293, \chi^{2}=2.350, p=0.125$ ). As to the modals of different types, only Chinese EFL learners' use of low-value modals in writing is significantly higher than that in speaking (106 vs. 145, $\chi^{2}=6.060, p=0.014$ ), though the other two types are also higher in writing than in speaking. In another terrain, it can be also concluded that either in speaking or in writing Chinese EFL learners use low-value modals the most, and the middle-value modals the least. As for specific modals, Chinese EFL learners tend to significantly overuse ought in writing than in speaking, while no such traits are found among other modal verbs.

As a whole, Chinese EFL learners use more can, will, should and must both in speaking and in writing, but the use of ought, shall and might are much less used by Chinese EFL learners. In terms of genres, it can be seen that Chinese learners tend to use should, need, will, would, can and may in writing, while in speaking they tend to choose must, have to, shall and could.

Table 4. The use of modal verbs by Chinese EFL learners

\begin{tabular}{llllllll}
\hline Types & Modal & Speaking & Writing & $\chi^{2}$ & $p$ \\
& & RF & SF & RF & SF & & \\
\hline Hight-value & must & 2039 & 16 & 1427 & 14 & 0.133 & 0.715 \\
& should & 3994 & 32 & 4462 & 44 & 1.895 & 0.169 \\
& need & 623 & 5 & 1251 & 12 & 2.882 & 0.090 \\
& ought & 10 & 0.08 & 60 & 0.6 & 63261.557 & $0.000^{* *}$ \\
& have to & 1294 & 10 & 854 & 8 & 0.222 & 0.637 \\
& SUM & 7960 & 66 & 8054 & 79 & 1.803 & 0.179 \\
\hline Middle-value & will & 6040 & 48 & 5584 & 55 & 0.476 & 0.490 \\
& would & 1357 & 11 & 1372 & 14 & 0.360 & 0.594 \\
& shall & 96 & 0.8 & 62 & 0.6 & .000 & 1.000 \\
& SUM & 7493 & 59 & 7018 & 70 & 0.769 & 0.380 \\
\hline Low-value & can & 10943 & 87 & 11330 & 112 & 3.141 & 0.076 \\
& could & 1413 & 11 & 966 & 10 & 0.048 & 0.827 \\
& may & 883 & 7 & 2231 & 22 & 7.759 & 0.050 \\
& might & 175 & 1 & 151 & 1 & 0.000 & 1.000 \\
& SUM & 13414 & 106 & 14678 & 145 & 6.060 & $0.014 *$ \\
\hline TOTAL & & 28867 & 229 & 29750 & 293 & 2.350 & 0.125 \\
\hline
\end{tabular}

Note. $\mathrm{RF}=$ Raw Frequency; $\mathrm{SF}=$ Standardized Frequency (per 10, 000 words). $*<0.05 ; * *<0.01$. 
To conclude, Chinese EFL learners use more modal verbs in writing than in speaking, and the use of high-, middle- and low-value modal verbs are also respectively higher in writing than in speaking, though only the overuse of low-value modals reaches the significant level. Generally speaking, Chinese EFL learners use low-value modals the most, while the middle-value modals the least. In addition, the modals of should, need, ought, will, would, can and may are mainly used in writing, and must, have to, shall and could are mainly used in speaking.

\subsection{Native English Speakers' Use of Modal Verbs}

From Table 5, it can be seen that native English speakers significantly overuse modal verbs in speaking than in writing ( 172 vs. $128, \chi^{2}=6.453, p=0.011$ ). In terms of values, native English speakers use high-value modals the least either in speaking or in writing, while they use low-value modals the most in speaking and the middle-value modals the most in writing. Though native English speakers used all the three types of high-, middle- and low-value modals more frequently in speaking than in writing, only the use of low-value modals reaches the significantly level ( 80 vs. $48, \chi^{2}=8.000, p=0.005$ ). In addition, native English speakers tend to use can, should, need, ought, would, shall, could and might in speaking, while such modals as must, will and may occur more frequently in writing.

Table 5. The use of modal verbs by native English speakers

\begin{tabular}{llllllll}
\hline Types & Modal & \multicolumn{2}{l}{ Speaking } & \multicolumn{2}{l}{ Writing } & $\chi^{2}$ & $p$ \\
& & RF & SF & RF & SF & & \\
\hline High-value & must & 755 & 4 & 610 & 5 & 0.111 & 0.739 \\
& should & 1902 & 11 & 1142 & 9 & 0.200 & 0.655 \\
& need & 1688 & 10 & 592 & 5 & 1.667 & 0.197 \\
& ought & 261 & 2 & 64 & 0.5 & 0.333 & 0.564 \\
& have to & 2283 & 6 & 766 & 6 & 0.000 & 1.000 \\
& SUM & 6889 & 33 & 3174 & 26 & 0.831 & 0.362 \\
\hline Middle-value & will & 3712 & 22 & 3807 & 30 & 1.231 & 0.267 \\
& would & 5969 & 35 & 3114 & 24 & 2.051 & 0.152 \\
& shall & 284 & 2 & 94 & 0.7 & 0.333 & 0.564 \\
& SUM & 9965 & 59 & 7015 & 54 & 0.140 & 0.708 \\
\hline Low-value & can & 7858 & 46 & 2164 & 17 & 13.349 & $0.000^{* *}$ \\
& could & 3062 & 18 & 1886 & 15 & 0.273 & 0.602 \\
& may & 1112 & 7 & 1458 & 11 & 0.889 & 0.346 \\
& might & 1585 & 9 & 675 & 5 & 1.143 & 0.285 \\
& SUM & 13617 & 80 & 6183 & 48 & 8.000 & $0.005^{* *}$ \\
\hline TOTAL & & 30471 & 172 & 16372 & 128 & 6.453 & $0.011^{*}$ \\
\hline
\end{tabular}

It can be concluded that native English speakers mainly use modal verbs in speaking, and they disprefer the use of modal verbs in writing partly due to the subjectivity conveyed by these verbs. In addition, native English speakers use low-value modals the most in speaking, while they use middle-value modals the most frequently in writing. However, either in speaking or in writing native English speakers use high-value modals the least. In terms of specific verbs, the modal verbs of can, should, need, ought, would, shall, could and might are more speaking-oriented, but the modals of must, will and may are more writing-oriented.

\subsection{The Comparison on the Use of Modal Verbs between Chinese EFL Learners and Native English Speakers}

\subsubsection{The Comparison of Modal Verbs in Speaking}

Table 6 indicates that Chinese EFL learners significantly overuse modal verbs in speaking than native speakers ( 229 vs. $172, \chi^{2}=8.102, p=0.004$ ). As to modals of different values, Chinese EFL learners overuse all the three types of modal verbs in comparison to native English speakers, but only the overuse of high-value modals reaches the significant level (63 vs. 33, $\chi^{2}=9.375, p=0.002$ ). For specific words, Chinese EFL learners significantly overuse such modals as must, should, will and can, but they significantly underuse would and might in speaking. 
Table 6. The use of modal verbs in speaking by Chinese EFL learners and native English speakers

\begin{tabular}{llllllll}
\hline \multirow{2}{*}{ Type } & Modal & \multicolumn{2}{l}{ Chinese Learners } & \multicolumn{2}{l}{ Native Speakers } & $\chi^{2}$ & $p$ \\
& & RF & SF & RF & SF & & \\
\hline High-value & must & 2039 & 16 & 755 & 4 & 7.200 & $0.008^{* *}$ \\
& should & 3994 & 32 & 1902 & 11 & 10.256 & $0.002^{* *}$ \\
& need & 623 & 5 & 1688 & 10 & 1.667 & 0.197 \\
& ought & 10 & 0.08 & 261 & 2 & 166.747 & $0.000^{* *}$ \\
& have to & 1294 & 10 & 2283 & 6 & 1.000 & 0.317 \\
& SUM & 7910 & 63 & 6889 & 33 & 9.375 & $0.002^{* *}$ \\
\hline Middle-value & will & 6040 & 48 & 3712 & 22 & 9.657 & $0.002^{* *}$ \\
& would & 1357 & 11 & 5969 & 35 & 12.522 & $0.000^{* *}$ \\
& shall & 96 & 0.8 & 284 & 2 & 0.333 & 0.564 \\
& SUM & 7493 & 59 & 9965 & 59 & 0.008 & 0.927 \\
\hline Low-value & can & 10943 & 87 & 7858 & 46 & 12.639 & $0.000^{* *}$ \\
& could & 1413 & 11 & 3062 & 18 & 1.690 & 0.194 \\
& may & 883 & 7 & 1112 & 7 & 2.001 & 0.157 \\
& might & 175 & 1 & 1585 & 9 & 6.400 & $0.011^{*}$ \\
& SUM & 13414 & 106 & 13617 & 80 & 3.634 & 0.057 \\
& & 28867 & 229 & 30471 & 172 & 8.102 & $0.004^{* *}$ \\
\hline
\end{tabular}

Note. $* \mathrm{P}<0.05 ; * * \mathrm{P}<0.01$

\subsubsection{The Comparison of Modal Verbs in Writing}

In writing (Table 7), Chinese EFL learners use more modal verbs than native English speakers, and the difference has reached the significant level ( 293 vs. $\left.128, \chi^{2}=64.667, p=0.000\right)$. As to the types, Chinese EFL learners significantly overuse high-value ( 78 vs. $\left.25, \chi^{2}=26.752, p=0.000\right)$ and low-value modals (145 vs. 48 , $\left.\chi^{2}=48.751, p=0.000\right)$ in writing than native English speakers. Specifically, Chinese EFL learners significantly overuse must, should, will and can in writing in comparison to native English speakers, while they tend to underuse (though not significantly) such modals as would, shall, could and might.

Table 7. The use of modal verbs in writing by Chinese EFL learners and native English speakers

\begin{tabular}{llllllll}
\hline Type & Modal & \multicolumn{2}{l}{ Chinese Learners } & \multicolumn{2}{l}{ Native Speakers } & $\chi^{2}$ & $p$ \\
& & RF & SF & RF & SF & & \\
\hline High-value & must & 1427 & 14 & 610 & 5 & 4.263 & $0.039^{*}$ \\
& should & 4462 & 44 & 1142 & 9 & 23.113 & $0.000^{* *}$ \\
& need & 1251 & 12 & 592 & 5 & 2.882 & 0.090 \\
& ought & 60 & 0.6 & 64 & 0.5 & 0.000 & 1.000 \\
& have to & 854 & 8 & 766 & 6 & 0.286 & 0.593 \\
& SUM & 8054 & 78 & 3174 & 25 & 26.752 & $0.000^{* *}$ \\
\hline Middle-value & will & 5584 & 55 & 3807 & 30 & 7.353 & $0.007^{* *}$ \\
& would & 1372 & 14 & 3114 & 24 & 2.632 & 0.105 \\
& shall & 62 & 0.6 & 94 & 0.7 & 0.000 & 1.000 \\
& SUM & 7018 & 70 & 7015 & 55 & 1.800 & 0.180 \\
\hline Low-value & can & 11330 & 112 & 2164 & 17 & 69.961 & $0.000^{* *}$ \\
& could & 966 & 10 & 1886 & 15 & 1.000 & 0.317 \\
& may & 2231 & 22 & 1458 & 11 & 3.667 & 0.056 \\
& might & 151 & 1 & 675 & 5 & 2.667 & 0.102 \\
& SUM & 14678 & 145 & 6183 & 48 & 48.751 & $0.000^{* *}$ \\
\hline
\end{tabular}

Thus, it can be concluded that Chinese EFL learners tend to overuse modal verbs in writing than native English speakers do, either in total frequency, different types, or in specific words like must, shall, will and can.

\section{Discussion}

After a corpus-based analysis of how Chinese EFL learners and native English speakers use modal verbs, the study arrives at the following conclusions:

(1) Native English speakers use significantly more modal verbs in speaking than in writing, which indicates the 
speaking-oriented feature of modal verbs. Chinese EFL learners, however, do not distinguish the use of modal verbs in different genres. This shows that Chinese EFL learners have a lower degree of genre awareness, as illustrated in Wen et al. (2003).

(2) Native English speakers tend to use can, should, need, ought, would, shall, could and might in speaking, while such modals as must, will and may mainly occur in writing. As for Chinese EFL learners, they mainly use must, have to, shall and could in speaking, and in writing they prefer to use should, need, will, would, can and may. In comparison, Chinese EFL learners mistakenly employ should, would, can and will in writing, which are mainly used in speaking by native speakers. In addition, the modal must has a strong tendency to be used in writing, but Chinese EFL learners mainly use it in speaking. This, again, reveals Chinese EFL learners' low awareness of genre knowledge.

(3) In comparison with native English speakers, Chinese EFL learners significantly overuse high-value modal verbs in speaking in general, and such significant overuse also exist among must, should, will and can. However, Chinese EFL learners significantly underuse would and might in speaking. In writing, Chinese EFL learners significantly overuse high-value and low-value modal verbs in general, and the modal verbs of must, should, will and can in particular. That is to say, Chinese EFL learners significantly overuse high-value modals either in speaking or writing, with must and should in particular. The overuse of high-value modals, most probably, makes the utterances more impolite and offensive (Altman, 1990). In similar situations, native English speakers tend to choose need so as to highlight responsibility (Zheng, 1999), or they might use semi-modals like have to, be going to, and used to.

\section{Conclusion}

Based on a corpus analysis, the study examines the use of modal verbs by Chinese EFL learners and native English speakers. It further verifies the claim that there are many features of spoken language in L2 writing, which has been pointed out by Cobb (2003) and Wen et al. (2003). Another key feature of Chinese EFL learners' overuse of high-value modal verbs, which might cause their utterances less polite and more imposing. It is believed this overuse might be caused by the L1 transfer, in which the semantic meanings or semantic prosodies of modal verbs differ from one language to another. For example, the counterpart of should is yinggai (应该) in Chinese. However, should in English entails a sense of duty or responsibility, while in Chinese it can also convey a sense of advice. If Chinese EFL learners transfer the meaning of providing advice from Chinese to English, errors will occur. In this sense, it is strongly advisable to present to students the nuanced differences of modal verbs in different languages so as to reduce negative transfers from L1 to L2.

\section{Acknowledgement}

This research is supported by The Foundation of Philosophy and Social Science Research in Colleges and Universities in Jiangsu Province (2017SJB1074).

\section{References}

Aijmer, K. (2002). Modality in Advanced Swedish Learners' Written Interlanguage. In S. Granger, J. Hung, \& Petch-Tyson (Eds.), Computer Learner Corpora, Second Language Acquisition and Foreign Language Teaching. Amsterdan: John Benjamins Publishing Company. https://doi.org/10.1075/1llt.6

Altman, R. (1990). Giving and Taking Advice Without Offense. In R. C. Scarcella, E. J. Andersen, \& S. D. Krashen (Eds.), Developing Communicative Competence in a Second Language. New York: Newbury House.

Biber, D. et al. (1999). Longman Grammar of Spoken and Written English. Harlow: Person Education Limited.

Chang, J. (1987). Chinese Speakers. In M. Swan \& B. Smith (Eds.), Learner English. Cambridge: Cambridge University Press.

Cheng, X. \& Qiu, J. (2007). The use of modal verbs in Chinese EFL learners' compositions: A corpus-based study. Technology Enhanced Foreign Language Education, 6, 9-15.

Cobb, T. (2003). Analyze Late Interlanguage with Learner Corpora: Quebec Replications of Three European Studies. Canadian Modern Language Review, 3, 393-423. https://doi.org/10.3138/cmlr.59.3.393

Guo, X. (2005). Modal Auxiliaries in Phraseology: A Contrastive Study of Learner English and NS English. Corpus Linguistics 2005 Conference.

Halliday, M. A. K. (1994). An Introduction to Functional Grammar (2nd ed.). London: Edward Arnold.

Hinkel, E. (1995). The use of modal verbs as a reflection of cultural values. TESOL Quarterly, 2, 325-343. 
http://dx.doi.org/10.2307/3587627

Hong, G., \& Yu, Z. (2007). A pragmatic analysis of modality in written interlanguage. Foreign Languages in China, 6, 42-46.

$\mathrm{Hu}, \mathrm{Z}$. et al. (1982). Some linguistic differences in the written English of Chinese and Australian students. Language Learning and Communication, 1, 39-49.

Hyland, K., \& Milton, J. (1997). Qualification and certainty in L1 and L2 students' writing. Journal of Second Language Writing, 2, 183-205. https://doi.org/10.1016/s1060-3743(97)90033-3

Kasper, G. (1979). Communication strategies: Modality reduction. Interlanguage Studies Bulletin, 4, 266-283.

Leech, G. (1983). Principles of Pragmatics. London: Longman.

Li, Z. (2000). Modality: Extension from sentence to text. Foreign Language Research, 4, 6-12.

Major, D. (1974). The Acquisition of Modal Auxiliaries in the Language of Children. The Hague: Mouton.

McEnery, T., \& Kifle. (2002). Epistemicmodality in argumentative essays of second language writers. In J. Flowerdew (Ed.), Academic Discourse. London: Pearson Education Limited.

Papafragou, A. (2000). Modality: Issues in the Semantics-Pragmatics Interface. Oxford: Elsevier.

Salsbury, T., \& Bardovi-Harlig, K. (2000). Oppositional Talk and the acquisition of modality in L2 English. In B. Swierzbin et al. (Eds.), Social and Cognitive Factors in Second Language Acquisition. Somerville, MA: Cascadilla Press.

Wang, Q. (2005). A corpus analysis of Chinese EFL learners use of modal verbs. Journal of Haerbin University, $6,132-134$.

Wen, Q. et al. (2003). Features of oral style in English composition of advanced EFL learners: An exploratory study by contrastive learner corpus analysis. Foreign Language Teaching and Research Press, 4, 268-274.

Yang, Y. (1998). The impact of modal verbs and vague language on the styles of academic writing. Foreign Languages and Their Teaching, 7, 24-25, 35.

Zheng, X. (1999). Influence of oriental cultural values on the use of English modal verbs. Journal of University of Shanghai for Science and Technology, 1, 43-46.

\section{Copyrights}

Copyright for this article is retained by the author(s), with first publication rights granted to the journal.

This is an open-access article distributed under the terms and conditions of the Creative Commons Attribution license (http://creativecommons.org/licenses/by/4.0/). 